\title{
7-Türkçe öğretmeni adaylarının salgın dönemindeki uzaktan eğitim uygulamaları sürecinde Türkçe dersi okul deneyimi ve öğretmenlik uygulamasında karşılaştıkları sorunlar'1
}

\begin{abstract}
APA: Kırcı, A. (2022). Türkçe öğretmeni adaylarının salgın dönemindeki uzaktan eğitim uygulamaları sürecinde Türkçe dersi okul deneyimi ve öğretmenlik uygulamasında karşılaştıkları sorunlar. RumeliDE Dil ve Edebiyat Araştırmalar Dergisi, (26), 125-142. DOI: 10.2900o/rumelide.1073857.
\end{abstract}

Ali KIRCI

\section{$\ddot{\mathbf{O z}}$}

Dünyayı etkisi altına alan Covid-19 salgını turizmden sanayiye, hizmet sektöründen eğitime kadar insan faaliyetlerinin ciddi anlamda etkilenmesine neden olmuş; faaliyet alanlarında birtakım düzenlemeleri zorunlu kılmıştır. Toplum sağlı̆̆ını tehdit eden salgın nedeniyle yüz yüze eğitim uygulamalarına ara verilmiş, uzaktan eğitime geçiş yapılmıştır. Eğitim kurumlarının tüm kademelerinin hızlı bir şekilde uzaktan eğitime geçiş sağlaması beraberinde birtakım sorunları getirmiştir. Bu sorunları tespit etmek amacıyla gerçekleştirilen bu araştırmada Türkçe derslerinde yaşanan sorunlar belirlenmeye çalışılmıştır. Süreci daha iyi anlayabilmek için ise araştırmanın çalışma grubu sınıf içerisinde hem gözlemci hem de eğitimci rolünü üstlenen 22 Türkçe öğretmen adayından oluşturulmuştur. Araştırmada nitel araştırma yöntemlerinden durum çalışması deseni kullanılmış; veri toplama aracı olarak ise Türkçe dersindeki sorunlara yönelik verileri detaylı olarak elde edebilmek için araştırmacı tarafından geliştirilen yarı yapılandırılmış görüşme formu kullanılmıştır. Bu form ile okul deneyimi ve öğretmenlik uygulamasına katılmış olan öğretmen adaylarının Türkçe derslerinde yaşanan sorunlara yönelik görüşleri alınmıştır. Toplanan veriler içerik analizi yöntemi kullanılarak çözümlenmiş ve raporlaştırılmıştır. Araştırmanın sonucunda sanal sınıf ortamından, öğretmenlerden, öğrencilerden, öğretmen adaylarından ve materyallerden kaynaklanan birçok sorunun olduğu görülürken temel dil becerileri ve dil bilgisi öğretimi sürecinde de birçok sorunun ortaya çıtığı tespit edilmiştir. Öğretmen adaylarının belirttiği sorunlar incelendiğinde ise sanal sınıflarda yönetim sorunları, platform kaynaklı sorunlar, öğretmen ve öğretmen adaylarının dijital beceri yetersizliği, öğrencilerin yaşadıkları motivasyon kaybı, derslerde etkileşim eksikliği ve ders sürelerinin yetersizliği gibi birçok sorunun ön plana çıtığı görülmüştür.

Anahtar kelimeler: Uzaktan eğitim, okul deneyimi, Türkçe öğretmen adayları, öğretmenlik uygulaması, sorunlar

Bu çalışmanın bir bölümü, 28-30 Mayıs 2021'de düzenlenen Uluslararası Ankara Kongresi’nde 'Türkçe Öğretmeni Adaylarının Salgın Dönemindeki Uzaktan Eğitim Uygulamaları Sürecinde Okul Deneyimi ve Öğretmenlik Uygulaması Dersinde Karşılaştıkları Sorunlar' adlı başlık altında sözlü bildiri olarak sunuldu.

Arş. Gör., Artvin Çoruh Üniversitesi, Eğitim Fakültesi, Türkçe ve Sosyal Bilimler Eğitimi Bölümü, Türkçe Eğitimi ABD (Artvin, Türkiye), alikirci@artvin.edu.tr, ORCID ID: 00oo-0002-7733-1890 [Araştırma makalesi, Makale kayıt tarihi: 13.01.2022-kabul tarihi: 20.01.2022; DOI: 10.29000/rumelide.1073857]

Adres | Address

RumeliDE Dil ve Edebiyat Araştırmalar Dergisi $\quad$ RumeliDE Journal of Language and Literature Studies Osmanağa Mahallesi, Mürver Çiçeği Sokak, No:14/8 $\quad$ Osmanağa Mahallesi, Mürver Çiçeği Sokak, No:14/8 Kadıköy - ISTANBUL / TÜRKIYE 34714 Kadıköy - ISTANBUL / TURKEY 34714 e-posta: editor@rumelide.com e-mail: editor@rumelide.com, tel: +90 505 7958124, +90 2167730616 phone: +90 505 7958124, +90 2167730616 


\title{
The problems faced by Turkish teacher candidates during the distance education practices in the epidemic period, the school experience of the Turkish lesson and the problems they encountered in the teaching practice
}

\begin{abstract}
The Covid-19 epidemic, which affected the world, has seriously affected human activities from tourism to industry, from the service sector to education; It has made some regulations compulsory in its fields of activity. Due to the epidemic that threatens public health, face-to-face education practices have been suspended and distance education has been transitioned. The rapid transition of all levels of educational institutions to distance education has brought with it some problems. In this research, which was carried out to determine these problems, the problems experienced in Turkish lessons were tried to be determined. In order to better understand the process, the study group of the research was composed of 22 Turkish teacher candidates who assumed the role of both an observer and an educator in the classroom. The case study design, one of the qualitative research methods, was used in the research; As a data collection tool, a semi-structured interview form developed by the researcher was used in order to obtain detailed data on the problems in the Turkish lesson. With this form, the opinions of teacher candidates who participated in school experience and teaching practice about the problems experienced in Turkish lessons were taken. The collected data were analyzed and reported using the content analysis method. As a result of the research, it has been determined that there are many problems arising from the virtual classroom environment, teachers, students, teacher candidates and materials, while many problems arise in the process of teaching basic language skills and grammar. When the problems stated by the pre-service teachers were examined, it was seen that many problems such as management problems in virtual classrooms, platform-related problems, lack of digital skills of teachers and teacher candidates, loss of motivation experienced by students, lack of interaction in lessons and insufficient course durations came to the fore.
\end{abstract}

Keywords: Distance education, school experience, Turkish teacher candidates, teaching practice, problems

\section{Giriș}

Sürekli değişen ve gelişen teknoloji ile birlikte geleneksel öğretim uygulamaları yerini teknoloji tabanlı öğretim uygulamalarına bırakmaya başlamıştır. 21. yüzyılın başından itibaren teknolojiye uyum sağlama açısından oldukça önemli bir yol kat eden eğitim faaliyetleri (Belet Boyacı ve Güner Özer, 2019; Firat, 2016), 2019 yılında yaşanan salgın sebebiyle dijital ortamların bir parçası hâline gelmiş, toplum sağlığını korumak için birçok ülke yüz yüze eğitime ara vererek uzaktan eğitime geçişmiştir (Millî Eğitim Bakanlığı [MEB], 2020a). Türkiye'de de 18 Mart 2020 tarihli basın açıklamasıyla salgın sürecinde alınması ön görülen tedbirler kapsamında uzaktan eğitim uygulamalarına geçiş yapılmıştır. Uzaktan eğitime geçiş kararının ardından eğitim kurumları sürecin hızlı bir şekilde yapılandırılması için çalışmalara başlamıştır. Öğrencilerin eğitim hakkından yararlanabilmesi için Millı̂ Eğitim Bakanlığı ilk olarak TRT EBA kanalı üzerinden ders videoları paylaşmış, ilerleyen süreçte eşzamanlı olarak sanal sınıflarda derslerin gerçekleştirilmesi için gerekli çalışmaları tamamlamıştır. Yüksek Öğretimde ise uzaktan eğitimin verimini artırmak için Uzaktan Eğitim Platformu (UZEP) ve Uzaktan Eğitim Kapısı gibi platformlar kullanılmaya başlanmıştır. 2021-2022 eğitim öğretim yılına kadar Yüksek Öğretim Kurumlarında işlenen dersler tamamen uzaktan yürütülmüş, Millî Eğitim Bakanlığına bağlı okullarda ise zaman zaman yüz yüze eğitime geçiş denemeleri yapılmasına rağmen dersler çoğunlukla uzaktan

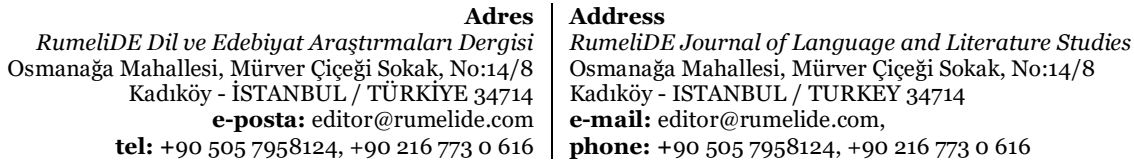


eğitim yoluyla işlenmiştir (MEB, 2021; Yükseköğretim Kurulu [YÖK], 2021). Bu süreçte eğitim fakültelerinde öğrenim görmekte olan öğretmen adaylarının okul deneyimi ve öğretmenlik uygulaması dersleri de sanal sınıf ortamında gerçekleştirilmiştir.

Öğretmenlik uygulaması, öğretmen adaylarının eğitim fakültelerinde edindikleri bilgi ve becerileri hizmet öncesinde işlevsel olarak yapılandırmalarına, deneyim kazanmalarına ve kendilerini geliştirmelerine imkân tanıyan uygulamalı bir derstir (YÖK, 1998). Öğretmen adaylarının meslek hayatına donanımlı bir şekilde hazırlanmasına hizmet eden bu uygulama; adayların genel kültür, özel alan eğitimi ve öğretmenlik mesleğiyle ilgili bilgi, beceri ve tutumlarının gelişmesini sağlar (MEB, 2020b). Öğretmen adaylarının üniversite eğitim hayatında öğrendikleri teorik bilgileri uygulamaları için zemin hazırlayan öğretmenlik uygulaması dersleri, aynı zamanda gözlem yapmaya da firsat sunar. Öğretmen adayları gözlem yoluyla öğretmenlik mesleğiyle ilgili eksiklikler, teorik bilgilerin yeterlilikleri ve öğrenci ilgi ve ihtiyaçları hakkında bilgi sahibi olacağı gibi öğrenme ortamlarındaki sorunların belirlenmesi konusunda da bakış açısı kazanırlar. Bu nedenle aynı sınıfta hem eğitimci hem de gözlemci rolünü üstlenen öğretmen adaylarının süreç hakkındaki görüşleri, eğitim öğretim faaliyetlerinin sağlıklı bir şekilde yapılandırılması için önemli veriler sağlayabilir. Alanyazın incelendiğinde birçok araştırmada öğrenme ortamı sorunlarını belirlemek amacıyla öğretmenlik uygulamasına katılan öğretmen adaylarının görüşlerine başvurulduğu görülmektedir (Kale, 2011; Kırksekiz, Uysal, İşbulan, Akgün, Kiyıcı ve Horzum, 2015).

Eğitim öğretim faaliyetlerinin gerçekleştirildiği öğrenme ortamları; eğitimin verimini artırmak için çağın koşulları, öğrencilerin ilgi ve ihtiyaçları, öğretim yaklaşımları gibi birçok unsur dikkate alınarak yapılandırılır. Çağdaş yaklaşımlar da eğitim uygulamaları planlanırken öğrenci odaklı bir tutum sergilemeyi ön görür (Demirel, 2005). Değişen koşullar dikkate alınarak yapılandırılan öğrenme ortamlarının sürekli olarak zenginleştirilme ihtiyacı, diğer derslerde olduğu gibi Türkçe öğretiminde de nitelikli bir eğitimin gerçekleştirilmesi için gereklidir. Bu sebeple alanyazında ana dili olarak Türkçe öğretimi, ilköğretim ve ortaöğretim kademelerinde Türkçe öğretimi, yabancılara Türkçe öğretimi gibi birçok konuda eğitim öğretim uygulamalarını iyileştirmek için süreçte yaşanan sorunları belirlemeye yönelik yapılan araştırmalar vardır (Arslan, 2017; Erdoğan ve Gök, 2009; Korkmaz, 2018).

Erdoğan ve Gök'ün (2009) Türkçenin ana dili olarak öğretiminde yaşanan sorunları tespit etmek ve bu sorunlara çözüm önerileri geliştirmek amacıyla geçekleştirdiği araştırmada Türkçe derslerinde zaman konusunda yaşanan sorunlar, sınıf yönetimi sorunları, öğretmen adaylarının deneyim yetersizlikleri, öğrencilerden kaynaklanan sorunlar ve fiziki imkânların yetersizliği gibi birçok soruna dikkat çektiği görülmektedir. Babayiğit ise (2017) ilkokul birinci sınıf Türkçe öğretimi dersindeki sorunları tespit etmek ve bu sorunlara çözüm önerileri geliştirmek amacıyla gerçekleştirdiği araştırmasında Türkçe öğretiminde yaşanan sorunları beş tema altında toplamıştır. Bu sorunlar; okul ve sınıfın fiziksel yapısının yetersiz olması, velilerin öğrencilere karşı yeterli ilgiyi göstermemesi, öğrenciden kaynaklanan sorunlar, öğrenci yaşından kaynaklanan sorunlar ve velilerin öğrencilerde yanlış öğrenme yaşantıları oluşturmasıdır. Yüz yüze eğitim uygulamaları sürecinde gerçekleştirilen araştırmaların ilgili alan yazına önemli katkı sağladığı bir gerçektir ancak değişen yaşam koşulları sonucunda bir yıldan uzun bir süre boyunca uzaktan eğitim faaliyetlerinin deneyimlenmiş olması ve teknoloji temelli eğitim anlayışının giderek kabul görmesi, günümüz koşullarındaki Türkçe öğretimindeki sorunlar üzerine çlkarımda bulunma ihtimalini zayıflatmaktadır. Gelişen teknoloji ile birlikte eğitim uygulamalarının her geçen gün zenginleştirildiği düşünüldüğünde salgın sürecinde deneyimlenen uzaktan eğitim uygulamalarının gelecek eğitim planlamalarında önemli bir yerinin olacağı söylenebilir. Bu nedenle uzaktan eğitim sürecindeki Türkçe derslerinde yaşanan sorunların hem gözlemci hem de eğitimci olarak sınıf içerisinde

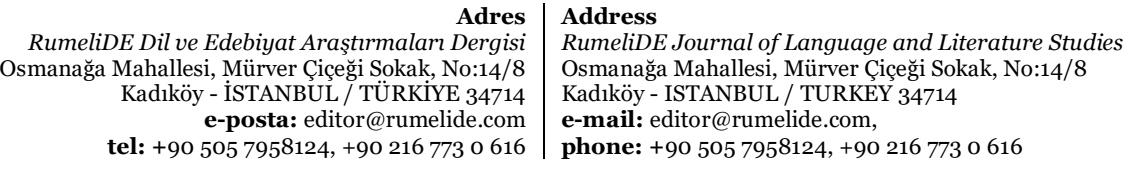


bulunan öğretmen adaylarının görüşlerine başvurarak tespit edilmesinin eğitim öğretim faaliyetlerine katkı sağlayacağı düşünülmektedir.

\section{Yöntem}

\section{Araştırmanın modeli}

Araştırmada nitel araştırma modelleri arasında sıklıkla tercih edilen durum çalışması araştırma deseni kullanılmıştır. Nitel araştırma, bireylerin farklı bakış açılarını kayda geçmeyi, herhangi bir probleme ait çeşitli faktörleri saptamayı ve genel bir tablo oluşturmayı içerir (Creswell, 2021). En yaygın olarak kullanılan nitel araştırma yöntemleri arasında bulunan durum çalışması deseni, insanların çevrelerinde olup bitenleri nasıl anlamlandırdığı ile ilgilenir. Yin’e (2003) göre durum çalışması, araştırmacının değişkenleri kontrol etmediği güncel bir durumu neden ve nasıl sorularını kullanarak araştırmasıdır. Mevcut durumun detaylı bir şekilde anlaşılması için tercih edilen bu desen bir duruma ilişkin etkenlerin bütüncül bir yaklaşımla değerlendirilmesine imkân sağlar (Yıldırım ve Şimşek, 2011). Bu nedenle uzaktan eğitim sürecindeki Türkçe dersi okul deneyimi ve öğretmenlik uygulaması derslerinde karşılaşılan sorunların belirlenmesi amacıyla durum çalışması deseni kullanılmıştır. Güncel durumun içerisinde hem gözlemci hem de eğitimci rolünü üstlenen öğretmen adaylarının bir yll boyunca katıldıkları derslere yönelik görüşleri ortaya konulmuştur.

\section{Çalışma grubu}

Çalışma grubu oluşturulma sürecinde amaçlı örnekleme yöntemlerinden kolay ulaşılabilir durum örneklemesi kullanılmıştır. Araştırmaya hız ve pratiklik kazandırmak için yakın ve erişilmesi kolay olan örneklemlerin tercih edildiği bu yöntem (Ylldırım ve Şimşek, 2018) verilerin toplanmasında kolaylık sağlamaktadır. Araştırmanın çalışma gurubunu Karadeniz bölgesindeki bir üniversitede 2020-2021 eğitim öğretim yllında öğrenim gören 4. sınıf Türkçe öğretmenleri oluşturmaktadır. Okul deneyimi ve öğretmenlik uygulaması dersleri Türkçe öğretmenliği müfredatında 4. sınıfta yer aldığı için ilgili üniversitede öğrenim gören 22 Türkçe öğretmeni adayı çalışmaya dâhil edilmiştir.

\section{Veri toplama araçları}

Araştırmada kullanılan verilerin toplanma sürecinde görüşme tekniği tercih edilmiştir. İncelenen durum hakkında ayrıntılı bilgiye ulaşmak için tercih edilen görüşme tekniği, araştırmacı tarafından oluşturulan yarı yapılandırılmış görüşme formu kullanılarak uygulanmıştır. Formun oluşturulma sürecinde ilgili alan yazın incelenmiş, benzer araştırmalarda kullanılan formlar derlenmiş ve alan uzmanlarının görüşleri alınmıştır. Elde edilen bilgiler dikkate alınarak yarı yapılandırılmış görüşme formu oluşturulmuş ve oluşturulan form alan uzmanlarına sunulmuştur. Alan uzmanlarının görüşleri dikkate alınarak yapılandırılan form Türkçe derslerinde yaşanan sorunları belirlemek amacıyla araştırma sürecine dâhil edilmiştir. Veri toplama aracında yer alan sorular şunlardır:

Uzaktan eğitim sürecinde uygulama öğretmeninden kaynaklanan sorunlar nelerdir? Açıklayınız.

Uzaktan eğitim sürecinde öğrencilerden kaynaklanan sorunlar nelerdir? Açıklayınız.

Uzaktan eğitim sürecinde sınıf ortamından (sanal sınıf) kaynaklanan sorunlar nelerdir? Açıklayınız.

Uzaktan eğitim sürecinde kullanılan materyalden kaynaklanan sorunlar nelerdir? Açılayınız.

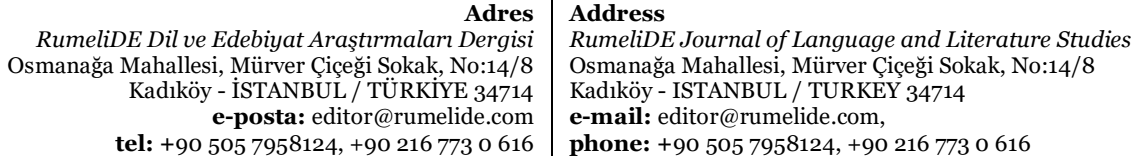


Uzaktan eğitim sürecinde temel dil becerileri etkinlikleri ile ilgili gözlemlediğiniz sorunlar nelerdir? Açıklayınız.

Uzaktan eğitim sürecinde dil bilgisi öğretimi ile ilgili yaşanan sorunlar nelerdir? Açıklayınız.

Uygulama dersleri sürecinde öğretmen adaylarından kaynaklanan sorunlar nelerdir? Açıklayınız.

Diğer sorunlara yönelik tespitleriniz nelerdir? Açıklayınız.

\section{Veri toplama süreci}

Yarı yapılandırılmış görüşme formları Google Classroom üzerinden oluşturulan bağlantı aracıllğıyla öğretmen adayları ile paylaşılmış, öğretmen adaylarına gözlemledikleri sorunları daha ayrıntılı olarak ifade edebilmeleri için süre verilmiştir. Bir haftalık sürenin sonunda oluşturulan bağlantı kullanılarak öğretmen adaylarının görüşleri toplanmıştır.

\section{Verilerin analizi}

Araştırma sürecinde elde edilen veriler içerik analizi tekniği kullanılarak çözümlenmiştir. Genellikle yazılı belge, günlük veya görüşme metinleri gibi dokümanların çözümlenmesinde kullanılan içerik analizi (Patton, 2020), eğitim araştırmalarında ayrıntılı analiz amacıyla tercih edilmektedir. "İçerik analizinde temel yapılan işlem, birbirine benzeyen verileri belirli kavramlar ve temalar çerçevesinde bir araya getirmek ve bunları okuyucunun anlayabileceği bir biçimde düzenleyerek yorumlamaktır." (Yıldırım ve Şimşek, 2011, s. 227). Verilerin geçerlik ve güvenirliğinin sağlanması için ise öğretmen adaylarının görüşleri iki farklı alan uzmanı tarafından kodlanmış, araştırmacıların kodlamaları arasındaki güvenirlik kat sayısı \%95 olarak tespit edilmiştir. Kodlamalardaki farklılıklar tekrardan gözden geçirilerek ortak bir karara varılması sağlanmış, ulaşılan veriler frekans ve yüzdelik değerleri ile tablolaştırılmıştır. Ayrıca araştırmanın geçerliğini artırmak için öğretmen adaylarının görüşleri (ÖAx) doğrudan alıntılanmıştır.

\section{Bulgular}

Bu bölümde Türkçe öğretmeni adaylarının okul deneyimi ve öğretmenlik uygulaması dersinde karşılaştıkları sorunlara ilişkin görüşler tablolar hâlinde sunulmuştur. Tablo açıklamalarında ilgili sorunlara dair görüş bildiren öğretmen adaylarının görüşlerine yer verilmiştir.

Tablo 1 Türkçe öğretmen adaylarının uzaktan eğitim platformundan kaynaklanan sorunlara ilişkin görüşleri

Temalar

İletişimin sağlıklı biçimde gerçekleşmemesi

Çevrim içi olması nedeniyle sınıf kontrolünün sağlanamaması

Kullanılan platformların yeterince geliştirilmemiş olması

Uzaktan eğitim platformunda yapılan derslerin süresinin yetersiz olması

\begin{tabular}{|c|c|}
\hline Katılımcılar & $\mathrm{f}$ \\
\hline 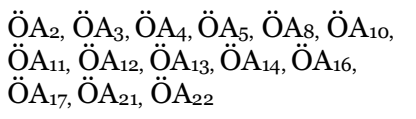 & 14 \\
\hline 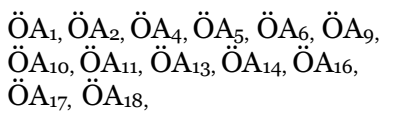 & 13 \\
\hline $\begin{array}{l}\mathrm{OA}_{1}, \mathrm{OA}_{4}, \mathrm{OA}_{6}, \mathrm{OA}_{11}, \mathrm{OA}_{12}, \mathrm{OA}_{14} \text {, } \\
\mathrm{OA}_{15}, \mathrm{OA}_{16}, \mathrm{ÖA}_{18}, \mathrm{ÖA}_{20}, \mathrm{OA}_{22}\end{array}$ & 11 \\
\hline $\begin{array}{l}\mathrm{ÖA}_{2}, \mathrm{ÖA}_{8}, \mathrm{ÖA}_{12}, \mathrm{ÖA}_{14}, \mathrm{ÖA}_{16} \text {, } \\
\text { ÖA }_{17}, \mathrm{OA}_{22} \text {, }\end{array}$ & 7 \\
\hline
\end{tabular}

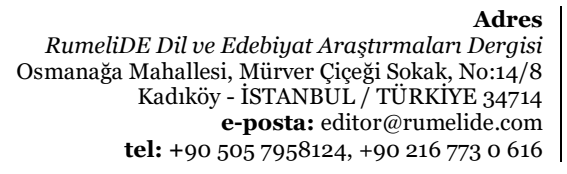

Adres

RumeliDE Journal of Language and Literature Studies

Osmanağa Mahallesi, Mürver Çiçeği Sokak, No:14/8

Kadıköy - ISTANBUL / TURKEY 34714

e-mail: editor@rumelide.com,

phone: +90 5057958124 , +90 2167730616 
The problems faced by Turkish teacher candidates during the distance education practices in the epidemic period, the school experience of the Turkish lesson and the problems they encountered in the teaching practice / A. Kurc1 (pp. 125-142)

Derslerin ev ortamında işlenmesinden kaynaklı olarak dış etkenlerden olumsuz etkilenmesi

Somut sınıf ortamı olmaması nedeniyle öğrencilerin dersi ciddiye almaması

Sanal sınıf yapısının bazı konu ve etkinliklere elverişli olmaması

\begin{tabular}{|c|c|}
\hline $\begin{array}{l}\mathrm{ÖA}_{5}, \mathrm{OA}_{7}, \mathrm{Ö}_{10}, \mathrm{ÖA}_{16}, \mathrm{ÖA}_{17} \text {, } \\
\mathrm{O}_{19} \text {, }\end{array}$ & 6 \\
\hline $\mathrm{ÖA}_{5}, \mathrm{ÖA}_{6}, \mathrm{ÖA}_{19}$ & 3 \\
\hline $\mathrm{ÖA}_{8}, \mathrm{ÖA}_{18}$ & 2 \\
\hline Toplam & 56 \\
\hline
\end{tabular}

Çalışmaya katılan öğretmen adaylarının uzaktan eğitim sürecinde katıldıkları okul deneyimi ve öğretmenlik uygulaması derslerindeki uzaktan eğitim platformu (Zoom) ile ilgili gözlemlerine ilişkin görüşlerine tablo 1'de yer verilmiştir. Öğretmen adaylarının \%25’i somut ortam olmamasından kaynaklı olarak iletişim sorunları olduğunu, \%23’ü çevrim içi olması sebebiyle sınıf kontrolünün sağlanamadığını, \%20'si platformun yeterince geliştirilmediğini, \%12'si ders sürelerinin yetersiz olduğunu, \%11’i ev ortamından kaynaklanan sorunlar çıktığını, \%5’i öğrencilerin dersi ciddiye almadığını, \%4’ü ise sınıf yapısının bazı konu ve etkinliklere uygun olmadığını belirtmiştir. Öğretmen adaylarının görüşlerinden bazıları aşağıda alıntılanmıştır.

"Genel olarak hazırlıklı bir eğitim planı değildi bu yüzden eksiklerini çok yaşadık. ...uzaktan eğitimde kullanılan platformlar herhangi bir pilot uygulaması olmadan kullanıma sunuldu. Eksik giderme aşaması çok uzun sürdü ve hala devam etmekte. Ülke olarak uzaktan eğitim sürecine hazır olmadan bu yönteme zorunlu olarak geçtik ve bunun tamamen düzgün hale gelmesi kısa sürede imkânsız gibi görünüyor $\left(\ddot{O} A_{16}\right)$."

"Belki biraz basit görünen ancak en büyük problemlerden biri olan bir problem; öğretmenin, sorduğu sorulara cevap vermek isteyen öğrencileri görememesi ve belki de söz hakkı almak isteyen bir öğrenciyi görmedi diye öğretmenine ya da derse küsen öğrencilerin oluşması. Bu, öğrencinin kendini değersiz hissetmesine neden olabilir. Katıldı̆̆m derslerin neredeyse hepsinde bu duruma şahit oldum $\left(\ddot{O} A_{2}\right)$.”

“Öğrenciler sanal sınıfta kameraların ya da seslerini açmıyor. Kamera ya da seslerini açmamaları iletişimi çok etkiliyor. Sanki karşında kimse yokmuş gibi bir his uyandırıyor $\left(O \ddot{O} A_{12}\right)$."

Tablo 2 Türkçe öğretmen adaylarının öğretmenlerden kaynaklanan sorunlara ilişkin görüşleri

Temalar

Derse karşı gereken ilginin gösterilmemesi

Öğretim teknoloji ve materyalleri konusunda dijital becerilerin yetersizliği

Sinıf yönetiminin sağlanamaması

Sosyal yaşam ve iş hayatı arasındaki dengenin kurulmaması

Geleneksel öğretim yöntem, teknik ve materyallerinin kullanılması

\begin{tabular}{|c|c|}
\hline Katılımcılar & $\mathrm{f}$ \\
\hline 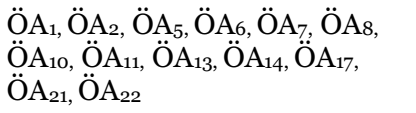 & 13 \\
\hline $\begin{array}{l}\mathrm{ÖA}_{2}, \mathrm{Ö}_{3}, \ddot{\mathrm{OA}_{4}}, \mathrm{Ö}_{5}, \mathrm{Ö}_{6}, \mathrm{Ö}_{7} \text {, } \\
\text { ÖA }_{10}, \mathrm{OA}_{12}, \mathrm{OA}_{17}\end{array}$ & 9 \\
\hline $\mathrm{ÖA}_{3}, \mathrm{OA}_{4}, \mathrm{OA}_{6}, \mathrm{Ö}_{10}, \mathrm{OA}_{15}, \mathrm{Ö}_{16}$ & 6 \\
\hline $\mathrm{ÖA}_{1}, \mathrm{OA}_{4}, \mathrm{OA}_{5}, \mathrm{Ö}_{12}, \mathrm{ÖA}_{13}, \mathrm{OA}_{21}$ & 6 \\
\hline $\mathrm{OAA}_{4}, \mathrm{OA}_{6}, \mathrm{OA}_{17}, \mathrm{Ö}_{10}, \mathrm{Ö}_{20}$ & 5 \\
\hline
\end{tabular}

Toplam

Öğretmen adaylarının uzaktan eğitim sürecinde uygulama öğretmeninden kaynaklanan sorunlara ilişkin görüşleri incelendiğinde \%33’ü öğretmenlerin gerekli ilgiyi göstermediklerini, \%23’u öğretim teknolojileri ve dijital materyal kullanımı konusunda öğretmenlerin sorun yaşadıklarını, \%13’i ise öğretmenlerin geleneksel öğretim yöntemi ve materyali kullandığını ifade etmiştir. Dijital beceri yeterliliğinin istenilen düzeyde olamamasının diğer iki sorunu da ortaya çıkardığı söylenebilir. Diğer taraftan öğretmen adaylarının \%16’sı sınıf yönetimi konusunda yaşanan sorunlara, \%15'i ise sosyal yaşam ve iş hayatındaki dengenin kurulamadığına dikkat çekmiştir. Öğretmen adaylarının görüşleri

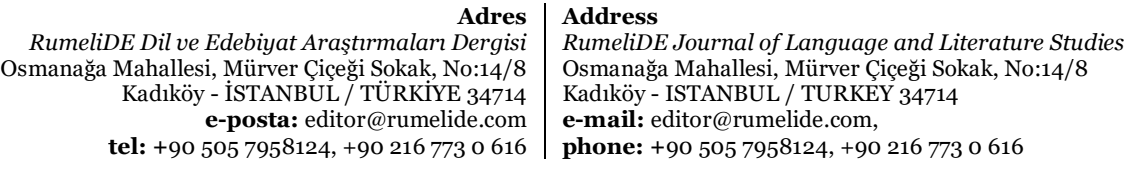


ayrıntılı olarak incelendiğinde ise tüm bu sorunların ana sebeplerinden birisinin dijital beceri yetersizliği olduğu görülmektedir. Öğretmen adaylarının görüşlerinden bazıları aşağıda alıntılanmıştır.

"Uzaktan eğitim sürecinde uygulama öğretmeninden kaynaklanan başhca sorunun "ilgisizlik" olduğunu düşünüyorum. Öğrencilerle doğrudan temasa geçilmediği ayn zamanda verilen ödevleri, yapılan etkinlikleri ya da olası herhangi bir araştırmayı öğretmen doğrudan kontrol edemediği için öğretmende, öğrenciye karşı bir ilgisizliğin oluştuğunu düşünüyorum (ÖA $\left.A_{2}\right)$.”

"Birçok öğretmenin ise teknolojik aletleri kullanma konusunda ve "Teknoloji Çağı"na ayak uydurmalarında zorlandıkların görüyorum. Bu durum da bir süre sonra öğretmenlerin kendilerini teknolojiyi kullanma açısından yetersiz görmelerine ve bu konuda kendilerini eksik hissetmelerine neden olmaktadır. Hatta bu durum, teknolojik açıdan yetersiz olan öğretmenlerin sinıftaki otoritesini ve öğrencinin gözündeki değeri zedelemektedir $\left(\ddot{O ̈}_{6}\right)$.”

"Birinci dönem dersi beraber işlediğimiz uygulama hocamızın sanal sınıfta dersin hâkimiyetini çok çabuk kaybedebiliyordu $\left(\ddot{O} A_{15}\right)$."

Tablo 3 Öğretmen adaylarının öğrencilerden kaynaklanan sorunlara ilişkin görüşleri

Temalar

Motivasyon kaybı ve derse karşı ilgisiz tutum sergileme

Öğrencilerin sosyo-ekonomik farklılıkları nedeniyle ders veriminin düşmesi

Teknolojik sorunların bahane edilmesi

Uzaktan eğitim süreci ile ilgili uyum sorunu

Ders geçme kaygısının olmaması nedeniyle eğitimden uzaklaşma

Dersi sabote etme

\begin{tabular}{|c|c|}
\hline Katılımcılar & f \\
\hline 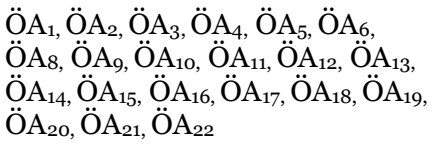 & 21 \\
\hline 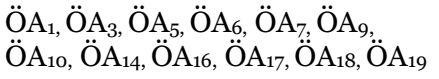 & 12 \\
\hline $\begin{array}{l}\mathrm{ÖA}_{1}, \mathrm{Ö}_{4}, \mathrm{OA}_{5}, \mathrm{Ö}_{6}, \mathrm{Ö}_{13}, \mathrm{ÖA}_{15} \text {, } \\
\mathrm{OHA}_{19}, \mathrm{ÖA}_{22}\end{array}$ & 8 \\
\hline $\begin{array}{l}\mathrm{ÖA}_{6}, \mathrm{OA}_{8}, \mathrm{Ö}_{9}, \mathrm{ÖA}_{12}, \mathrm{Ö}_{16}, \mathrm{ÖA}_{17} \text {, } \\
\text { ÖA }_{18}\end{array}$ & 7 \\
\hline $\mathrm{ÖA}_{1}, \mathrm{Ö}_{17}$ & 2 \\
\hline $\mathrm{O}_{20}, \ddot{O}_{22}$ & 2 \\
\hline Toplam & 52 \\
\hline
\end{tabular}

Uzaktan eğitim sürecindeki Türkçe derslerinde öğrenciden kaynaklı sorunlar hakkında öğretmen adaylarının biri hariç tümü öğrencilerin motivasyon kaybı yaşadıklarını ve derslere karşı gereken ilgiyi göstermediklerini belirtmişlerdir. Tüm temalar arasında öğretmen adaylarının en yüksek oranda fikir birliğine vardıkları görüşün motivasyon ve ilgi olması uzaktan eğitim sürecinde öğrencilerin durumu hakkında fikir sahibi olunması açısından oldukça önemlidir. Ayrıca öğretmenlerin \%23'ü öğrenciler arasındaki sosyo-ekonomik farklılıkların ders ortamına olumsuz yansıdığını,\%16’sı öğrencilerin ders esnasında teknolojik sorunları bahane ederek iş yükünden kaçma eğiliminde olduğunu, \%14'ü uyum sürecinde birtakım sorunlar yaşadıklarını, \%4’ü öğrencilerin dersi geçme kaygısı yaşamadıklarını, \%4’ü ise öğrencilerin dersi sabote ettiğini ifade etmiştir. Öğretmen adaylarının görüşlerinden bazıları aşă̆ıda alıntılanmıştır.

Öğrenciler siz söz hakkı vermediğiniz sürece söz hakkı almak istemiyorlar. Bazı öğrencilerin derse katılımları çok düşük $\left(O \ddot{O} A_{19}\right)$.”

"Bir başka sorunlardan biri de etkinlikler yapıldığı esnada cevap vermesi için seçilen öğrenciye ismiyle seslenildiği halde cevap vermiyordu veya o esnada mikrofonları bozulmuş oluyordu $\left(\ddot{O} A_{22}\right)$."

"Öğrencilerin telefondan dersleri yeterli şekilde takip etmemeleri dersi pek fazla ciddiye almak istememeleri çünkü her halükarda dersten geçeceklerini düşündükleri için bu durum derse katılımda azh̆ğı etkilemektedir $\left(\ddot{O} A_{17}\right)$.”

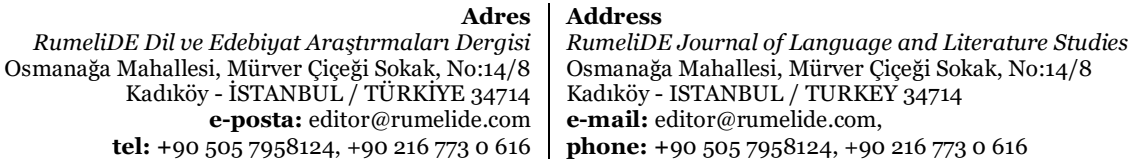

Adres
RumeliDE Dil ve Edebiyat Araşttrmalar Dergisi , Iürver Çiç Sokak, No:14/8 tel: +90 $5057958124,+902167730616$ 
The problems faced by Turkish teacher candidates during the distance education practices in the epidemic period, the school experience of the Turkish lesson and the problems they encountered in the teaching practice / A. Kurc1 (pp. 125-142)

Tablo 4 Öğretmen adaylarının kendilerinden kaynaklanan sorunlara ilişkin görüşleri

Temalar

Deneyim yetersizliği nedeniyle ders veriminin düşmesi

Sosyal yaşamdan kaynaklı olarak dersleri olumsuz etkileme

Öğretim teknoloji ve materyalleri konusunda dijital becerilerin yetersizliği

\begin{tabular}{|c|c|}
\hline Katılımcılar & $\mathrm{f}$ \\
\hline 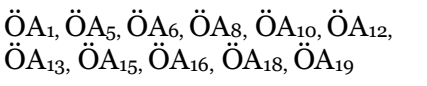 & 11 \\
\hline $\begin{array}{l}\mathrm{ÖA}_{2}, \mathrm{Ö}_{3}, \mathrm{Ö}_{6}, \ddot{\mathrm{O}} \mathrm{A}_{8}, \mathrm{Ö}_{10}, \mathrm{Ö}_{14} \text {, } \\
\mathrm{O}_{17}, \ddot{O}_{20}\end{array}$ & 8 \\
\hline $\begin{array}{l}\mathrm{ÖA}_{4}, \mathrm{ÖA}_{10}, \mathrm{OA}_{12}, \mathrm{ÖA}_{14}, \mathrm{ÖA}_{17}, \mathrm{Ö}_{19} \text {, } \\
\mathrm{OAA}_{21}\end{array}$ & 7 \\
\hline Toplam & 26 \\
\hline
\end{tabular}

Uzaktan eğitim sürecindeki okul deneyimi ve öğretmenlik uygulaması derslerinde öğretmen adaylarının kendilerinden kaynaklanan sorunlara ilişkin görüşleri incelendiğinde diğer temalardan daha az görüşün yer aldığı görülmektedir. Üç farklı görüş bildiren öğretmen adaylarının \%42'si deneyim sahibi olmadıklarını, \%31’i sosyal yaşamlarından kaynaklı olarak sanal sınıf ortamında yapılan derslerin olumsuz etkilendiğini, \%27’si ise öğretim teknolojisi ve dijital materyalleri kullanma konusunda yetersiz olduğunu belirtmiştir. Temada yer alan sorunların diğer temalara göre daha az olmasının öğretmen adaylarının öz eleştiri yapabilme becerileri hakkında birtakım ipuçları sunduğu söylenebilir. Öğretmen adaylarının görüşlerinden bazıları aşağıda alıntılanmıştır.

"Uzaktan eğitim sürecinde dil bilgisi konuların anlatmaya çekimser kalıyorum. Bir hata yaparım ya da bir ögrrenci bir soru sorar ve ben yanlş yantlartm diye çekiniyorum. En önemli sorun ise nasıl anlatacağımı bilmiyorum. O yüzden öğrencilere bunu daha önce duydunuz mu diye soruyorum ya da uygulama öğretmeninden yardım istiyorum (ÖA $\left.A_{8}\right)$."

"Uygulama derslerinde karşılaştığım en büyük problem ev oldu. Evde çalışma ortamının olmaması ve kalabalık bir aileye sahip olmam derslere katılmamı epey zorlaştırdı. Evdeyken kaçırdığım bir dersi telafi etmeye vaktimin olmaması dersten kopmama ve takip edemememe sebep oldu maalesef $\left(\ddot{\mathrm{O}} \mathrm{A}_{2}\right)$."

"Uygulama dersleri strasında benden kaynaklanan en büyük sıkıntı oturumu alamamam ve ekranı istediğim şekilde kontrol altına alamamam oldu $\left(\ddot{O} A_{19}\right) . ”$

Tablo 5 Öğretmen adaylarının materyal kullanımı sorunlarına ilişkin görüşleri

Temalar

Materyal kullanımında kullanılan donanım ve yazılımların sorun yaratmas

Uzaktan eğitim sürecinde materyal kullanımının sınırlı olması

Uzaktan eğitime uygun yeterli materyalin bulunmaması

Mevcut uzaktan eğitim materyallerin gereken nitelikte olmaması

Ders kitaplarının uzaktan eğitim sürecine uyarlanmış olmaması

\begin{tabular}{|c|c|}
\hline Katılımcılar & $\mathrm{f}$ \\
\hline 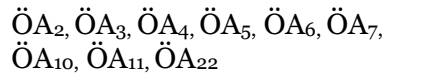 & 9 \\
\hline $\begin{array}{l}\mathrm{ÖA}_{3}, \mathrm{ÖA}_{4}, \mathrm{ÖA}_{6}, \mathrm{ÖA}_{8}, \mathrm{ÖA}_{9}, \mathrm{ÖA}_{13} \text {, } \\
\text { ÖA }_{17}, \mathrm{OA}_{20}, \mathrm{OA}_{21}\end{array}$ & 9 \\
\hline $\begin{array}{l}\mathrm{ÖA}_{1}, \mathrm{Ö}_{12}, \mathrm{ÖA}_{14}, \mathrm{ÖA}_{15}, \mathrm{OA}_{16}, \mathrm{ÖA}_{19} \text {, } \\
\mathrm{O}_{20}\end{array}$ & 7 \\
\hline 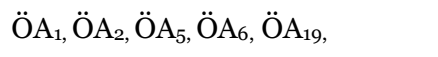 & 5 \\
\hline $\mathrm{Ö}_{1}, \mathrm{OA}_{6}, \mathrm{OA}_{16}, \mathrm{Ö}_{20}$ & 4 \\
\hline oplam & 4 \\
\hline
\end{tabular}

Türkçe öğretmeni adaylarının \%26’sı materyal için kullanılan donanım ve yazılımların süreci zorlaştırdığını, \%26’sı uzaktan eğitimin materyal kullanımını kısıtladığını ifade etmiştir. Uzaktan eğitim uygulamalarında kullanılan donanımların materyal konusunda birtakım sorunlar oluşturması altyapı ihtiyacını ortaya çıkardığı söylenebilir. Aynı temadaki öğretmen adaylarının \%21’i uzaktan eğitim sırasında Türkçe dersi için yeterli materyal olmadığını, \%15’i nitelikli materyal bulma konusunda sorun

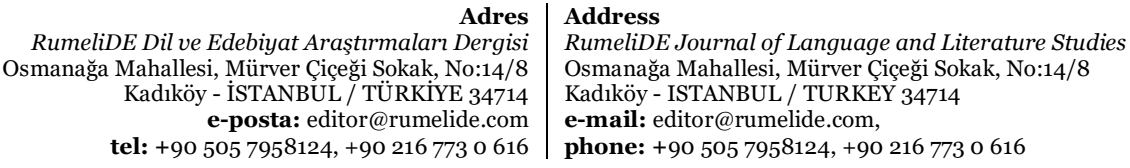


yaşadığını, \%12'si ise ders kitaplarının yüz yüze eğitim için oluşturulmuş olmasının süreci zorlaştırdığını belirtmiştir. Öğretmen adaylarının görüşlerinden bazıları aşağıda alıntılanmıştır.

"Karşılaştı̆̆ım sorunlarm başında video izletme sürecinde internetten ya da EBA'nın yoğunluğunda kaynakl 3 dakikalık videoyu 1 o dakikada izlemekti $\left(\ddot{O} A_{5}\right)$."

“Uzaktan eğitim sürecinde biz istediğimiz materyalleri kullanamıoruz (ÖA8).”

"Uzaktan eğitime geçiş kademeli olarak değil de bir anda olduğundan dolayı sanıyorum, uzaktan eğitime uygun materyaller sağlanmadiğından öğrencilere somut materyaller verme konusunda eksik kaliyoruz $\left(\ddot{O} A_{16}\right)$."

Tablo 6 Ö ğretmen adaylarının temel dil becerileri öğretimi sorunlarına ilişkin görüşleri

Temalar

Beceri alanlarına eşit derecede önem verilmemesi

Temel dil becerilerine dayalı etkinliklerin süre sınırına takılması

Dil becerileri öğretiminde yöntem ve stratejilere yer verilmemesi

Kontrol mekanizması zayıf olduğu için etkinliklerin verimsiz geçmesi

Temel dil becerisi etkinliklerine ev ortamının olumsuz yansimasi

Somut sınıf ortamı gerektiren etkinliklerin ötelenmesi

\begin{tabular}{|c|c|}
\hline Katılımcılar & $\mathrm{f}$ \\
\hline 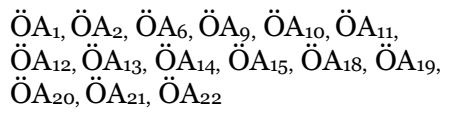 & 15 \\
\hline 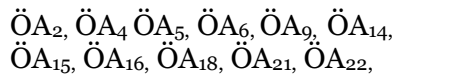 & 11 \\
\hline $\begin{array}{l}\mathrm{ÖA}_{3}, \mathrm{ÖA}_{4}, \mathrm{OA}_{6}, \mathrm{ÖA}_{10}, \mathrm{OA}_{11}, \mathrm{ÖA}_{13} \text {, } \\
\text { ÖA }_{14}, \mathrm{OA}_{16}\end{array}$ & 8 \\
\hline $\mathrm{ÖA}_{2}, \mathrm{OA}_{5}, \mathrm{ÖA}_{9}, \mathrm{ÖA}_{15}, \mathrm{ÖA}_{20}, \mathrm{ÖA}_{21}$ & 6 \\
\hline $\mathrm{OAA}_{4}, \mathrm{OA}_{6}, \mathrm{OA}_{7}, \mathrm{ÖA}_{16}, \mathrm{ÖA}_{17}, \mathrm{ÖA}_{19}$ & 6 \\
\hline $\mathrm{ÖA}_{6}, \mathrm{OA}_{7}, \mathrm{OA}_{13}, \mathrm{ÖA}_{15}, \mathrm{Ö}_{16}$, & 5 \\
\hline Toplam & 5 \\
\hline
\end{tabular}

Öğretmen adaylarının temel dil becerileri öğretiminde yaşanan sorunlara ilişkin görüşleri incelendiğinde \%29'u beceri alanlarına eşit derecede önem verilmediğini, \%21'i beceri alanlarına yönelik etkinliklerin ders sürelerinden dolayı olumsuz etkilendiğini, \%16'sı temel dil becerileri öğretiminde stratejilerden yeterince faydalanılmadığını, \%12'si sanal sınıflardaki kontrol mekanizmasının zayıf olması nedeniyle dil becerisi etkinliklerinin verimli geçmediğini, \%12'si ev ortamının etkinlikleri olumsuz etkilediğini, \%10'u ise somut ortam gerektiren etkinliklerin sanal sinıflarda gerçekleştirilemediğini belirtmiştir. Öğretmen adaylarının görüşlerinden bazıları aşă̆ıda alıntılanmıştır.

"Yazma etkinlikleri ise ödev olarak verilmekte bir sonraki dersin akışına göre ya dinleniliyordu ya da es geçiliyordu $\left(\ddot{O} A_{22}\right)$.”

"Okuma etkinliği yaparken öğrencilere yeterince zaman verip okuma yapturamıoruz süremiz kısıth olduğu için söz hakkı alan öğrenciler birer paragraf okuduklarında mecburen diğer söz hakkı isteyen öğrencilere okutturuyoruz bu durun ister istemez öğrencilerin okuma eğitimlerinde olumsuz sonuç yaratır $\left(\ddot{O} A_{18}\right)$."

"Dinleme becerisi ile ilgili geliştirilen etkinlikler dinleme yöntem ve teknikleri kullanılmadan yapılması o etkinliğin geliştirilme amacına ters düşüyor. Ne bir not alarak dinleme olsun, ne empatik dinleme olsun bu yöntemlere yönelik hiçbir etkinlik yok $\left(O \ddot{O} A_{13}\right)$."

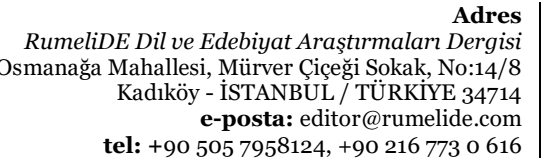

Adres
RumeliDE Dil ve Edebiyat Araşttrmaları Dergisi tel: +90 $5057958124,+902167730616$
Address

RumeliDE Journal of Language and Literature Studies Osmanağa Mahallesi, Mürver Çiçeği Sokak, No:14/8

Kadıköy - ISTANBUL / TURKEY 34714

e-mail: editor@rumelide.com,

phone: +90 505 7958124, +90 2167730616 
The problems faced by Turkish teacher candidates during the distance education practices in the epidemic period, the school experience of the Turkish lesson and the problems they encountered in the teaching practice / A. Kırc1 (pp. 125-142)

Tablo 7 Öğretmen adaylarının dil bilgisi öğretimi sorunlarına ilişkin görüşleri

Temalar

Dil bilgisi öğretimine yönelik uzaktan eğitim yöntem ve materyallerinin yetersiz olması

Dil bilgisi konularının somutlaştırılamaması

Öğrencilerin dil bilgisi konularına karşı ilgisiz tutum sergilemesi

Ders süresinin dil bilgisi konularını öğretmek için yetersiz olmasi

\begin{tabular}{|c|c|}
\hline Katılımcılar & $\mathrm{f}$ \\
\hline $\begin{array}{l}\mathrm{ÖA}_{1}, \mathrm{Ö}_{3}, \mathrm{Ö}_{4}, \mathrm{Ö}_{56}, \mathrm{Ö}_{6}, \mathrm{Ö}_{10} \text {, } \\
\mathrm{ÖA}_{14}, \mathrm{ÖA}_{18}, \mathrm{ÖA}_{19}, \text { ÖA }_{20},\end{array}$ & 10 \\
\hline $\begin{array}{l}\mathrm{ÖA}_{9}, \mathrm{Ö}_{13}, \mathrm{OA}_{15}, \mathrm{Ö}_{16}, \mathrm{ÖA}_{17}, \mathrm{ÖA}_{18} \text {, } \\
\mathrm{O}_{19}, \mathrm{OHA}_{21} \text {, }\end{array}$ & 8 \\
\hline $\begin{array}{l}\mathrm{ÖA}_{3}, \mathrm{Ö}_{5}, \mathrm{OA}_{12}, \mathrm{Ö}_{13}, \mathrm{Ö}_{14}, \mathrm{OA}_{20} \text {, } \\
\mathrm{OAA}_{21}, \mathrm{ÖA}_{22} \text {, }\end{array}$ & 8 \\
\hline $\mathrm{ÖA}_{4}, \mathrm{Ö}_{6}, \mathrm{Ö}_{16}, \mathrm{ÖA}_{22}$ & 4 \\
\hline Toplam & 30 \\
\hline
\end{tabular}

Öğretmen adaylarının \%33’ü dil bilgisi konularının öğretimi için uzaktan eğitime uygun yöntem ve materyallerin yeterli olmadı̆̆ına, \%27'si dil bilgisi konuların çevrim içi ortamlarda somutlaştırılmadığına, \%27'si somut sınıflarda dahi öğrencilerin dikkatini dil bilgisi konularına toplamanın zorluklarından bahsederek sanal sınıflarda bu durum daha da zorlaştığına ve öğrencilerin ilgisiz kaldığına, \%13’ü ise dil bilgisi konuları için sürelerin yetersiz olduğuna dikkat çekmiştir. Öğretmen adaylarının görüşlerinden bazıları aşağıda alıntılanmıştır.

"Dil bilgisi öğretimi diğer kazanımlar ve yetkinlikler gibi sunuş yoluyla kazandırlmaya çalsşllmaktadır. Bu durum da öğrencinin yaparak yaşayarak öğrenmesi sinurlandırlmakta ve öğretim havada kalarak kalıcılı̆̆ azalmaktadır. Bu da yetmez gibi materyal konusunda da çevrim içi derslere uyarlanması en zor konulardan birisi dil bilgisi. O nedenle materyal de bulamiyoruz $\left(\ddot{O} A_{10}\right) . "$

"Dil bilgisi konuları genel olarak sevilmeyen konulardır. Aslında öğrenilmesi diğer konulara göre daha zor olduğu için sevilmiyor bu da öğrencilere başarısızhğı getiriyor. Uzaktan eğitim de üzerine eklenince öğrencilerin dil bilgisi ile bağı neredeyse tamamen koptu $\left(\ddot{O} A_{3}\right)$.”

Tablo 8 Öğretmen adaylarının diğer sorunlara ilişkin görüşleri

Temalar

Alt yapıdan kaynaklı sorunlar

Öğretim programı ve müfredat sorunları

$\begin{array}{llc}\text { Katılımcllar } & \text { f } & \% \\ \text { ÖA }_{1}, \mathrm{Ö}_{3} \mathrm{Ö}_{4}, \mathrm{Ö}_{5}, \mathrm{OA}_{8}, \mathrm{Ö}_{9}, \mathrm{OA}_{10}, & 12 & 71 \\ \text { ÖA }_{11}, \mathrm{Ö}_{14}, \mathrm{OA}_{17}, \mathrm{OA}_{18}, \mathrm{OA}_{20} & & \\ \text { ÖA }_{2}, \mathrm{Ö}_{3} \mathrm{ÖA}_{5}, \mathrm{Ö}_{5}, \mathrm{OA}_{17}, \text { ÖA }_{22} & 5 & 29 \\ \text { Toplam } & 17 & 100\end{array}$

Türkçe öğretmen adaylarının uzaktan eğitim ile yürütülen okul deneyimi ve öğretmenlik uygulaması derslerindeki gözlemlerinden yola çıarak ifade ettikleri diğer sorunlar, alt yapıdan kaynaklı olarak derslerin olumsuz etkilenmesi ile öğretim programı ve müfredatını çevrim içi uygulamalar için uygun olmamasıdır. Öğretmen adaylarının görüşleri aşağıda alıntılanmıştır.

“İternet erişimi ve derslere katılım sağlayacak teknolojik aletinin herkeste istenilen özelliklerde olmaması $\left(\ddot{O} A_{17}\right)$."

"Yüz yüze yapılan müfredat uzaktan eğitime geçildiğinde tekrar bir değişiklik olmadı uzaktan eğitime göre planlanmadı bunun eksiklikleri fazlasıyla yaşandı $\left(\ddot{O} A_{3}\right)$.”

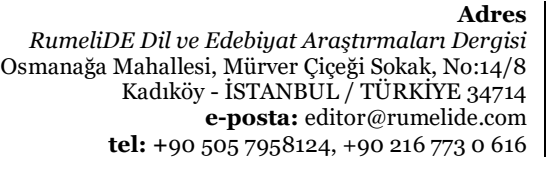

dres

RumeliDE Journal of Language and Literature Studies

Osmanağa Mahallesi, Mürver Çiçeği Sokak, No:14/8

Kadıköy - ISTANBUL / TURKEY 34714

e-mail: editor@rumelide.com,

phone: +90 5057958124 , +90 2167730616 


\section{Sonuç ve tartışma}

$\mathrm{Bu}$ araştırmada uzaktan eğitim ile yürütülen okul deneyimi ve öğretmenlik uygulaması Türkçe derslerinde öğretmen adaylarının gözlemlediği sorunlara ilişkin görüşleri belirlenmeye çalışılmıştır. Bu amaçla uzaktan eğitim yoluyla yapılan okul deneyimi ve öğretmenlik uygulaması dersine bir yıl boyunca katılım gösteren öğretmen adaylarının görüşlerine başvurulmuştur.

Araştırmaya katılan öğretmen adaylarının görüşleri incelendiğinde Türkçe dersinde yaşanan sorunlarla ilgili toplamda sekiz temanın ortaya çıktığı görülmektedir. Bu temalar içerisinde en fazla görüşün bildirildiği tema, sanal sınıftan kaynaklanan sorunlarla ilgilidir. Uzaktan eğitim uygulamalarının en önemli unsurlarından biri olarak görülen sanal sınıflar, somut öğrenme ortamlarına alternatif olarak öğrencilerin eğitim öğretim uygulamalarından faydalanmalarına imkân tanır (Toker Gökçe, 2008). Genel itibarıyla sınıf içerisindeki etkileşimi artırmak, farklı mekânlarda bulunan öğrencileri bir araya getirerek topluluk bilinci oluşturmak ve öğrenenlere kolay bir şekilde ulaşmak için tercih edilen bu ortamlar (Martin ve Parker, 2014), etkisini yoğun bir şekilde gösteren koronavirüs salgını ile birlikte eğitim faaliyetlerinin bir parçası hâline geldi. Uzaktan eğitim kararının esnetilmiş olmasına rağmen eğitim uygulamalarında hâlâ etkili olan sanal eğitim platformlarının gelecekteki eğitim planlamalarına doğrudan veya dolaylı bir şekilde etki etmesinin göz ardı edilemez bir gerçeğe dönüştüğü söylenebilir. Okul kademelerinde sağlanan yüz yüze eğitimler, salgın sürecindeki deneyimlerden yola çıarak uzaktan eğitim uygulamaları ile desteklenmeye başlandı. Bu gelişmeler dikkate alındığında sanal sınıf ortamları ile ilgili geri bildirimlerin gelecekte yapılandırılacak eğitim ortamları için önem arz ettiği söylenebilir. Araştırmanın bulguları incelendiğinde sanal sınıf ortamlarının sağlıklı iletişim kurma konusunda sorun oluşturduğuna, yapısı itibarıyla sınıf kontrolünde birtakım sorunlara neden olduğuna ve platformların yeterince geliştirilmemiş olmasından kaynaklı sorunların varlığına dikkat çeken görüşlerin ön plana çıktığı görülmektedir. Yapılandırmacı yaklaşıma dayalı öğrenme stratejileri dikkate alındığında ise sınıf içerisindeki etkileşimin öğretim süreçlerinin temelini oluşturduğu görülür (Hamzadayı, 2010). Bu nedenle sanal sınıflarda yaşanan iletişim sorunlarının etkileşimli öğretime engel oluşturacağı gibi öğrencilerin sosyal becerilerini de zayıflatacağı söylenebilir. Zira öğrencilerin öğrenmelerini yapılandırabilmeleri için bilginin alıcısı olarak konumlandırılan rolünden uzaklaşarak öğretmen ve diğer öğrencilerle etkili bir iletişim içerisinde olması gerekir (Koç, 2006). Sinıf kontrolünde yaşanan sorunlar dikkate alındığında ise bu sorunların sağlıklı öğrenme ortamlarının oluşturulmasının önünde büyük bir engel oluşturduğu söylenebilir. Sanal sınıflarda etkili öğrenme ortamı ve sınıf yönetiminin sağlanması için birtakım düzenlemelere ihtiyaç vardır (Kaya ve Ağaoğlu, 2013; Polat ve Boydak Özan, 2018). Eğitim uygulamalarının verimli bir şekilde gerçekleştirilebilmesi için çok sayıda araştırmacı tarafından yüz yüze eğitimde sınıf yönetimi ile ilgili araştırma yapıldı̆̆ı̆ görülmektedir (Aydın, 2017; Can ve Baksi, 2014; Güven ve Cevher, 2005; Kansızoğlu ve Erdoğan, 2015; Yeşilyurt ve Çankaya, 2008). Somut öğrenme ortamlarındaki sınıf yönetimi sorunlarının giderilmesi amacıyla yapılan bu araştırmaların sınıf yönetimi alanyazınına ve öğrenme sahasına katkı sağladığı ifade edilebilir. Uzaktan eğitim uygulamalarının yaygınlaşmasıyla birlikte de sanal sınıf yönetimi üzerine yapılan araştırmaların (Asim, Ponners, Bartlett, Parker, ve Star, 2020; Can, 2020; Kalelioğlu, Atan ve Çetin, 2016) sayısında artış gözlemlenmiştir. Arslan, Polat ve Bulut'un (2021) sanal sınıflarda sınıf yönetimi sorunlarını tespit etmek amacıyla gerçekleştirdiği araştırmasının sonuçları incelendiğinde de bu araştırmanın bulguları ile örtüştüğü görülmektedir. Araştırmacılar; öğretmenlerin ve öğrencilerin sanal sınıf eğitimine hazır olmaması, öğrencilerin istenmeyen müdahalelerinin dersi olumsuz etkilemesi ve iletişim sorunlarının dersin verimini düşürmesi gibi birçok sorun tespit etmişlerdir. Can (2020) ise sanal sınıf yönetiminin sağlıklı bir şekilde yapılandırılabilmesi için hizmet öncesi ve hizmet içi eğitimlere ihtiyaç duyulduğunu belirterek öğreticilerin sanal sınıf yönetimi değişkenleri, teknoloji kullanımı ve yönetimi, sanal sınıf

\footnotetext{
\begin{tabular}{r|l} 
Adres & Address \\
RumeliDE Dil ve Edebiyat Araştırmaları Dergisi & RumeliDE Journal of Language and Literature Studies
\end{tabular}

Osmanağa Mahallesi, Mürver Çiçeği Sokkak, No:14/8 $\quad$ Osmanağa Mahallesi, Mürver Çiçeği Sokak, No:14/8

Kadıköy - ISTANBUL / TURKIYE 34714 Kadıköy - ISTANBUL / TURKEY 34714

e-posta: editor@rumelide.com e-mail: editor@rumelide.com,

tel: +90 505 7958124, +90 2167730616 phone: +90 505 7958124, +90 2167730616
} 
The problems faced by Turkish teacher candidates during the distance education practices in the epidemic period, the school experience of the Turkish lesson and the problems they encountered in the teaching practice / A. Kurc1 (pp. 125-142)

yazılımları gibi birçok konuda yetiştirilmesi gerektiğini vurgulamıştır. Bu bağlamda teknolojik gelişmeler dikkate alınarak sanal sınıf ortamları hakkında yapılacak araştırmaların mevcut ve oluşabilecek sorunları giderme açısından faydalı olabileceği söylenebilir. Sanal sınıf yönetimini ve öğrenme ortamlarını etkileyen bir diğer unsur ise ilgili temada da ifade edilen sanal sınıf platformlarının yeterince geliştirilmemiş olmasıdır. Uzaktan eğitim platformları eğitim ortamlarında pek çok kolaylığı bünyesinde barındırması nedeniyle birçok etkinlikte aktif olarak kullanılmaktadır. Bu açıdan bakıldığında eğitim uygulamalarında kullanılacak platformların seçiminde kullanım amaçları dikkate alınmalıdır aksi takdirde ciddi kayıplara yol açabilir (Herand ve Hatipoğlu, 2014). Nitekim salgın sürecinde kullanılan EBA, Zoom ve çeşitli çevrim içi platformlarla ilgili sorunlara ilişkin birçok araştırma bulunmaktadır (Demir ve Özdaş, 2020; Erzen ve Ceylan, 2020; Telli, Kalaç ve Eronal, 2020; Zan, 2021). Örneğin Dilekçi (2021a) Türkçe eğitimi açısından EBA'yı değerlendirdiği araştırmasında öğretmenlerin platform kullanımı açısından kendilerini yeterli gördüklerini ancak EBA platformunun Türkçe dersleri için yetersiz olduğunu dile getirdiklerini ifade etmiştir. İlgili araştırmaların sonuçlarından da anlaşlacağı üzere ilerleyen süreçte eğitim uygulamalarının seyri dikkate alınarak uzaktan eğitim için kullanılan platformların geliştirilmesi, eğitim öğretim faaliyetlerinin iyileştirilmesi için atılacak önemli bir adımdır. Platform sorunlarına ek olarak uzaktan eğitim yoluyla yapılan derslerin 30 dakika ile sınırlandırılması (MEB, 2021) öğretmen adaylarının ifade ettiği bir diğer sorundur. Uzaktan eğitim araştırmalarının birçoğunda da bu soruna dikkat çekilmiştir (Yıldırım, 2020). Covid-19 sürecindeki eğitime ilişkin öğretmen görüşlerini değerlendiren Demir ve Özdaş (2020) eğitimin verimini düşüren bulgulardan birinin ders süreleriyle ilgili olduğunu ifade etmiştir. Öğretmenlerin ders sürelerini yetersiz gördüğü, ders sürelerinin artırılması gerektiğini belirttikleri hatta ek soru çözümü derslerine ihtiyaç duydukları araştırmanın öne çıkan bulguları arasında yer almaktadır. Benzer şekilde Başaran, Doğan, Karaoğlu ve Şahin (2020) de hem öğrencilerin hem de öğretmenlerin ders sürelerini kısa bulduklarını, süresi azalan derslerin öğrencilerin ve öğretmenlerin verimini düşürdüğünü ifade etmiştir. Diğer taraftan kısaltılan ders sürelerinin yeterli olduğuna ilişkin bulgulara ulaşan araştırmalar da vardır (Eraslan ve Yücel, 2021). Ancak araştırmanın bulgularında da görüldüğü üzere Türkçe dersi özelinde bakıldığında ders sürelerinin yetersiz olduğu, verimli öğrenme ortamları için sürelerin artırılması gerektiği söylenebilir.

Araştırmada sanal sınıf sorunlarının belirtildiği tablodan sonra en fazla görüşün yer aldığı tablo öğrencilerden kaynaklanan sorunlardır. Uzaktan eğitim uygulamalarının zaman ve mekânla ilgili sorunları ortadan kaldırma ve yüz yüze eğitim alamayacak durumda olan öğrenciler için alternatif oluşturma gibi olumlu katkıları vardır (Çivril, Aruğaslan ve Özaydın Özkara, 2018; Dilekçi, 2021b; Sahin ve Shelley, 2008; Valentine, 2002). Ancak bu katkılarının yanı sıra motivasyon kaybı, sosyal izolasyon ve dikkat dağınıklığı gibi öğrenci başarısını azaltan etkileri de olabilmektedir (Ilgaz ve Akşar, 2009). Araştırmanın bulguları incelendiğinde de öğretmen adaylarının öğrencilerde motivasyon kaybı ve derse karşı ilgisiz tutum gözlemledikleri görülmektedir. Alanyazındaki birçok çalışmada farklı kademelerdeki öğrencilerin uzaktan eğitim sürecinde motivasyon kaybı yaşadığı belirtilmiştir. Örneğin Şen ve Kızlcalığlu (2020), uzaktan eğitim sürecinde öğrencilerin yüz yüze eğitime oranla motivasyon kaybı yaşadığını ve motivasyon kaybı yaşayan öğrencilerin derslere katılımının zorlaştığını rapor etmiştir. Han, Demirbilek ve Demirtaş (2021) ise uzaktan eğitim sürecinde hem öğretmenlerin hem de öğrencilerin motivasyon kaybı yaşadıklarını ifade etmiştir. Dilekçi (2021b) ise deney ve kontrol grubu ile yürüttüğü araştırmasında motivasyon kaybına yönelik dikkate değer bulgulara ulaşmıştır. Deney grubunda 21. yüzyll becerilerine göre tasarlanan etkileşimli ve iş birlikçi etkinliklerle işlenen dersler sonucunda öğrenciler yüksek motivasyon sergilerken sunuş yoluyla öğretim yapılan kontrol grubundaki öğrencilerin motivasyonunun düştüğü görülmüştür. Bu bağlamda çevrim içi derslerde öğrenci

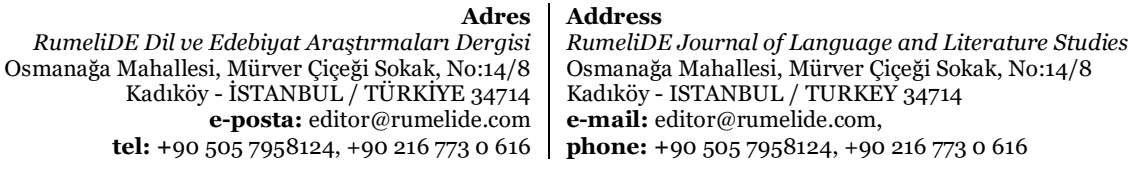


motivasyonunu yüksek tutmak için etkileşimli ders içeriklerinin oluşturulmasının önem kazandığı söylenebilir.

Uzaktan eğitim sürecinde yaşanan motivasyon kaybının diğer nedenlerinden biri de uyum sorunudur. Araştırmaya katılan öğretmen adaylarının da öğrencilerin uzaktan eğitim sürecine uyum sağlama konusunda bazı sorunlar yaşadığını ifade ettiği görülmektedir. Eğitim öğretim faaliyetlerinin tüm paydaşlarının uzaktan eğitim sürecine hazırlıksız yakalanmış olmaları uyum sorununu nispeten açılamaktadır. Nitekim bu durumun öğrenciler üzerinde psikolojik olarak olumsuz etkileri de vardır (Karakuş, 2020). Motivasyon kaybına yol açma ihtimali olan bir diğer sorun ise öğretmen adaylarının da ifade ettiği sosyo-ekonomik farklılıklardır. Sosyo-ekonomik farklılıklar nedeniyle ders veriminin düştüğünü ifade eden öğretmen adayları, öğrencilerin teknolojiye ulaşma konusunda birtakım sorunlar yaşadığına dikkat çekmiştir. Dijital uçurum olarak adlandırılan bu durum bilgi ve iletişim teknolojileri ile internet erişimi ve kullanımının sosyo-ekonomik duruma göre farklılaşmasıdır (Öztürk, 2005). Öğrencilerin çeşitli sebeplerden dolayı teknolojik aletlere ve internete istenilen düzeyde ulaşamaması dijital uçurumu artırdığı gibi öğrenme ortamının verimini de düşürmektedir. Hâlbuki Ağustos ayında yayımlanan Türkiye İstatistik Kurumunun verilerine göre Türkiye genelinde internet erişimine sahip olan hane oranı \%92'dir (TÜİK, 2021). Oldukça yüksek olan bu oran dikkate alındığında uzaktan eğitim sürecinde internete erişimin tek başına yeterli olmadığı görülmektedir. Alanyazında bu sonucu destekleyen birçok araştırma vardır (Öztürk, Kırcı ve Turan, 2021; Pınarcığlu, Kanbak ve Önver, 2021; Sezgin ve Firat, 2020). Diğer taraftan öğrencilerin teknolojik sorunları bahane ederek derslere katılmaması ve zaman zaman dersleri sabote etmesi gibi sorunlar için öğrencilere uzaktan eğitime uyum eğitiminin verilmesi faydalı olabilir (Cantürk ve Cantürk, 2021; Demirbilek, Demirtaş, Han ve Atila, 2021).

Araştırmanın öğretmen ve öğretmen adayları ile ilgili bulguları incelendiğinde dijital beceri yetersizliğinin ve geleneksel materyal kullanımının dikkat çektiği görülmektedir. Günümüz koşulları değerlendirildiğinde teknoloji kullanımının hayatın her alanında giderek arttığı söylenebilir. Özellikle teknoloji ile büyüyen bir neslin (Csobanka, 2016) öğrenci sıralarında eğitim aldığı günümüzde, eğitim faaliyetlerinin teknolojiden bağımsız olarak yürütülmesi düşünülemez. Ancak araştırmanın bulgularına paralel olarak birçok araştırmada öğretmen ve öğretmen adaylarının teknoloji ve dijital materyal kullanımı konusunda sorun yaşadığı ve kendilerini yetersiz gördüğü ifade edilmiştir (Avcı ve Güven, 2021; Karakuş ve Er, 2020; Yürektürk ve Coşkun, 2020). Bu bulgular uzaktan eğitim sürecinin materyal kullanımını kısıtlandırdığı, uzaktan eğitime uygun materyallerin bulunmadığı ve materyallerin gerekli nitelikte olmadığı görüşlerini de bir bakıma açıklamaktadır. Çünkü dijital beceri yeterliliği ve derse karşı sorumluklarının farkında olan eğitimciler için dijital materyal oluşturabilecekleri birçok ücretsiz platform vardır (Yıldız, 2020). Verimli öğrenme ortamlarının oluşturulabilmesi, iş birlikçi ve etkileşimli sınıf ortamlarının yapılandırılabilmesi için eğitimcilerin dijital beceri yeterliliklerinin geliştirilmesi gerektiği söylenebilir. Yaşanılan bu soruna ek olarak öğretmen adaylarının öğretmenlik deneyimlerinin de yeterli düzeyde olmaması uzaktan eğitim sürecini daha da zorlaştırmıştır. Nitekim öğretmenlik uygulaması ile ilgili yapılan araştırmalarda da öğretmen adaylarının daha fazla deneyim kazanabilmeleri amacıyla ders saatlerinin artırılması gerektiği vurgulanmıştır (Altıntaş ve Görgen, 2014). Diğer taraftan salgın sürecinde sosyal yaşam ve eğitim hayatı kavramlarının iç içe geçmiş olmasının eğitim uygulamalarını olumsuz etkilediği görülmektedir. Salgın sürecinde uzaktan eğitim hakkında yapılan birçok çalışmada da bu olumsuz etkiye değinilmiştir (Bulut ve Susar Kırmızı, 2021; Kurt, Kandemir ve Çelik, 2021).

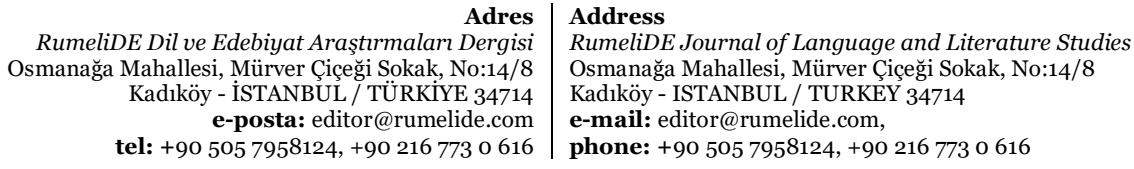


The problems faced by Turkish teacher candidates during the distance education practices in the epidemic period, the school experience of the Turkish lesson and the problems they encountered in the teaching practice / A. Kurc1 (pp. 125-142)

Temel dil becerileri öğretiminde karşılaşılan sorunlara ilişkin bulgular incelendiğinde öğretmen adaylarının altı farklı soruna dikkat çektiği görülür. Bu sorunlar içerisinde beceri alanlarına eşit derecede önem verilmediğini ve temel dil becerilerine dayalı etkinliklerin süre sınırına takıldığını ifade eden görüşler diğerlerine göre ön plana çıkmaktadır. Yüz yüze eğitime göre derslerin 10 dakika kısaltılmış (MEB, 2021) olmasının temel dil becerisi öğretimine olumsuz yansımaları olmuştur. Araştırmanın bulgularına paralel olarak salgın dönemi öncesinde dahi süre sorununa dikkat çeken araştırmalar vardır (Kırmacı ve Sami, 2018; Riasati, Allahyar ve Tan 2012). Ancak salgın sürecinde ders sürelerinin kısaltılmış olması okuma, yazma, konuşma ve dinleme becerilerinin öğretiminde süre sorununun artmasına neden olmuştur (Tanrıkulu, 2021). Öğretmen adaylarının görüşleri incelendiğinde ise ders sürelerinin kısaltılmasının eğitimcileri beceri alanları arasında seçime zorladığı görülür. Beceriler arasında yapılan seçimin ölçme değerlendirme etkinliklerine de olumsuz yansıdığı alıntılanan görüşlerde görülmektedir. Bu bulgular Karatay ve Dilekçi’nin (2019) çalışmasının sonuçlarıyla benzeşmektedir. Türkçe öğretmenlerinin ölçme değerlendirme yeterliliklerini değerlendiren araştırmacılar, öğretmenlerin temel dil becerilerini değerlendirme sürecine gereken önemi vermedikleri ve becerileri ölçme sürecini ihmal ettiklerini tespit etmiştir. Benzer şekilde Ünlü, Öztürk ve Tağa (2014) da Türkçe derslerinde ölçme değerlendirme sürecinde eşit bir değerlendirme yapılmadığını, okuma ve yazma becerilerine ağırlık verilirken konuşma ve dinleme becerilerinin geçiştirildiğini ifade etmiştir. Dil becerilerinde yöntem ve stratejilere yer verilmemesi ve kontrol mekanizması zayıf olduğu için etkinliklerin verimsiz geçmesine ilişkin görüşler incelendiğinde ise öğretmen ve öğretmen adaylarının dijital beceri yetersizliklerinin temel dil becerisi öğretiminde de sorun oluşturduğu söylenebilir. Birçok araştırmada da eğitimcilerin dijital beceri yetersizliklerinin eğitim öğretim faaliyetlerine olumsuz yansımalarının olduğu görülmektedir (Avcı ve Güven, 2021; Karakuş ve Er, 2020). Eğitimcilerin dijital materyal kullanımı konusunda yeterli donanıma sahip olmamasının eğitim faaliyetlerinin sağlıklı bir şekilde yürütülmesinin önünde engel oluşturduğu söylenebilir. Bu nedenle eğitimin tüm paydaşlarına dijital çağda eğitim öğretim uygulamalarını zenginleştirecek eğitimlerin verilmesi bu sorunun önüne geçmek için alternatif bir çözüm olabilir.

Dil bilgisi öğretimi ve diğer sorunlarla ilgili görüşler incelendiğinde öğretmen adaylarının dijital materyal hazırlama konusunda yeterli çabayı göstermedikleri, hazır materyallerin bulunmayışını sorun olarak nitelendirdikleri görülmektedir. Polat ve Tekin'in (2017) araştırmasının bulguları öğretmen adaylarının bu tutumunu açıklamak için fikir sunabilir. Öğretmen adaylarının e-içerik geliştirme becerilerini analiz etmek için 602 öğretmen adayına ulaşan araştırmacılar, araştırmada elde ettikleri bulgular sonucunda öğretmen adaylarının dijital materyal geliştirme konusunda birtakım kaygılar yaşadığını tespit etmiştir. Dijital beceri yetersizliğine ek olarak öğretmen adaylarının kaygı yaşamaları dijital materyal kullanımı konusunda hazıra yönelmelerine neden olmuş olabilir. Ayrıca öğretmen adaylarının alıntılanan görüşlerinde dil bilgisi konusunda kendilerini yeterli hissetmedikleri görülmektedir. Tüm bu olumsuzlukların bir arada olması öğretmen adaylarının dil bilgisi öğretiminde sorun yaşamasını anlaşılır kılmaktadır. Bu sorunların önüne geçmek için eğitim fakültelerindeki dil bilgisi öğretimi derslerinde birtakım düzenlemeler yapılarak gelecek nesillerin eğitimi için yetiştirilen öğretmenlerin donanımlı bir şekilde meslek hayatına başlaması sağlanabilir (Güven, 2013).

Sonuç olarak Türkçe öğretmeni adayları uzaktan eğitim sürecinde gerçekleştirilen Türkçe derslerinde yaşanan birçok sorunun olduğunu ifade ederek sanal platform, öğretmen, öğrenci ve kendilerinden kaynaklanan sorunlara dikkat çekmiştir. Tüm bu sorunların temel dil becerileri ve dil bilgisi öğretimine farklı biçimlerde yansıdığı görülmektedir. Türkçe derslerinde yaşanan sorunları en aza indirmek için eğitimin tüm paydaşlarına eğitim verilmesinin ve günümüz koşulları dikkate alınarak öğretim

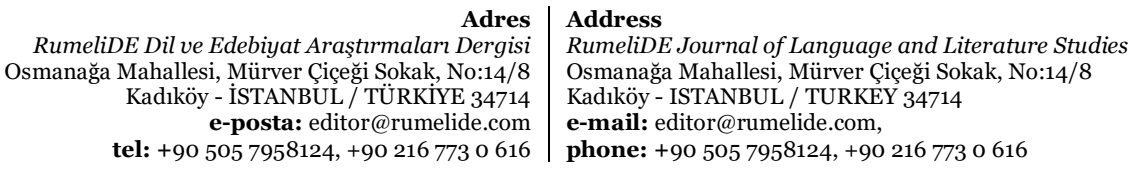


faaliyetlerinin tekrardan yapılandırılmasının Türkçe öğretimi konusunda olumlu sonuçlar ortaya koyacağı düşünülmektedir.

\section{Kaynakça}

Altıntaş, S., ve Görgen, İ. (2014). Sınıf öğretmeni adaylarının öğretmenlik uygulaması üzerine görüşleri (Muğla Sitkı Koçman Üniversitesi örneği). Turkish Studies, 9(8), 197-208.

Arslan, A. P. , Polat, S. ve Bulut, İ. (2021). Sanal sınıflarda sınıf yönetimi sorunları ve çözüm önerileri . Ĕ̆itim Yönetimi ve Politikalar Dergisi, 2(2), 39-54 .

Arslan, M. (2017). Ana dili olarak Türkçe öğretimi ve temel dil becerilerinin gelişiminde karşılaşılan sorunlar. Akademik Sosyal Araştırmalar Dergisi, 5(46), 63-77.

Asim, S., Ponners, P.J., Bartlett, C., Parker, M.A., ve Star, R. (2020). Differentiating Instruction: for middle school students in virtual learning environments. The Delta Kappa Gamma Bulletin: International Journal for Professional Educators, 19-30.

Avcı, B. ve Güven, M. (2021). Öğretmenlerin çevrim içi eğitime ilişkin hizmet içi eğitim gereksinimlerinin belirlenmesi . Dokuz Eylül Üniversitesi Buca Eğitim Fakültesi Dergisi , (51) , 345-367 . Doi: 10.53444/deubefd.882866

Aydın, A. (2017). Sınıf yönetimi. Ankara: Pegem Akademi.

Başaran, M. , Doğan, E. , Karaoğlu, E. ve Şahin, E. (2020). Koronavirüs (Covıd-19) pandemi sürecinin getirisi olan uzaktan eğitimin etkililiği üzerine bir çalışma. Academia Ĕ̆itim Araştırmaları Dergisi, 5(2) , 368-397.

Belet Boyacı, Ş. D. ve Güner Özer, M. (2019). Öğrenmenin Geleceği: 21. Yüzyll Becerileri Perspektifiyle Türkçe Dersi Öğretim Programları . Anadolu Journal of Educational Sciences International , Cilt: 9 Sayl: 2 , 708-738 . Doi: 10.18039/ajesi.578170

Bulut, S. ve Susar Kırmızı, F. (2021). Covid-19 salgını sürecinde uzaktan eğitimde Türkçe dersine ilişkin sınıf öğretmenlerinin görüssleri . Açıköğretim Uygulamaları ve Araştırmaları Dergisi, 7(4) , 1-30 . Doi: 10.51948/auad.960960

Can, E. ve Baksi, O. (2014). Öğrencilerin sınıf içi tutum ve davranışlarının öğretmenlerin sınıf yönetimi başarısına etkisi. Asya Öğretim Dergisi, 2(1), (Özel Sayı), 86-101.

Cantürk, G. ve Cantürk, A. (2021). İngilizce öğretmenlerinin Covid-19 küresel salgını sürecinde gerçekleştirdikleri uzaktan eğitim deneyimleriyle ilgili görüşlerinin metaforlar yoluyla belirlenmesi. Uluslararası Dil, Eğitim ve Sosyal Bilimlerde Güncel Yaklaşımlar Dergisi (CALESS), 3(1), 1-38.

Creswell, J. W. (2021). Nitel araştırma yöntemleri beş yaklaşıma göre nitel araştırma ve araştırma deseni. S. B. Demir ve M. Bütün (Çev. Ed.). Ankara: Siyasal Kitabevi

Csobanka, Z.E. (2016). The z generation. Acta Technologica Dubnicae 6(2), 63-76.

Çivril, H , Aruğaslan, E., ve Özaydın Özkara, B . (2018). Uzaktan Eğitim Öğrencilerinin Uzaktan Eğitime Yönelik Algıları: Bir Metafor Analizi. Eğitim Teknolojisi Kuram ve Uygulama, 8(1) , 39-59 . DOI: 10.17943/etku.310168

Demir, F., ve Özdaş, F. (2020). Covid-19 sürecindeki uzaktan eğitime ilişkin öğretmen görüşlerinin incelenmesi. Milli Ĕgitim Dergisi, 273-292 . DOI: 10.37669/milliegitim.775620

Demirel, Ö. (2005) Öğretimde Planlama ve Değerlendirme: Öğretme Sanatı. Ankara: Pegem A Yayınları.

Demirbilek, N., Demirtaş, H., Han, F., ve Atila, F. (2021). Okul yöneticisi ve öğretmenlerin bakış açısıyla uzaktan öğretim kavramı. Inonu University Journal of the Faculty of Education, 22(1), 446-470. Doi: 10.17679/inuefd.827706

Dilekçi, A. (2021a). Türkçe eğitimi açısından Eğitim Bilişim Ağı (EBA) . RumeliDE Dil ve Edebiyat Araştırmaları Dergisi , (25) , 1-17 . DOI: 10.2900o/rumelide.1032354

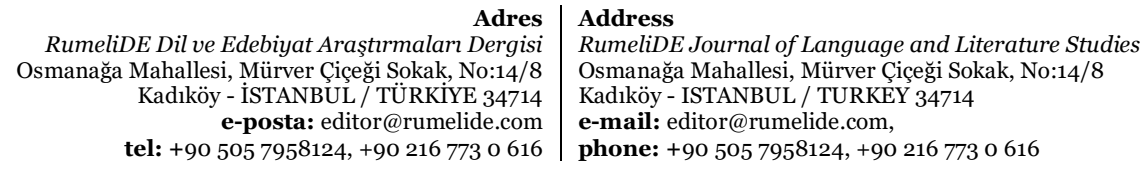


The problems faced by Turkish teacher candidates during the distance education practices in the epidemic period, the school experience of the Turkish lesson and the problems they encountered in the teaching practice / A. Kurc1 (pp. 125-142)

Dilekçi, A. (2021b). 21. yüzyl becerilerine göre tasarlanan öğretim etkinliklerinin eleştirel ve yaratıcı düşünme becerilerini geliştirmeye etkisi. (Yayımlanmamış Doktora Tezi). Bolu Abant İzzet Baysal Üniversitesi

Erdoğan T, ve Gök, B. (2009). Türkçenin ana dili olarak öğretiminde karşılaşılan sorunlar ve bu sorunların giderilmesine yönelik öneriler: Ankara örneği. Çukurova Üniversitesi Eğitim Fakültesi Dergisi, 3(36), 1 - 16.

Can, E. (2020). Sanal sınıf yönetimi: İlkeler, uygulamalar ve öneriler. Açıöğretim Uygulamaları ve Araştırmaları Dergisi, 6(4), 251-295.

Eraslan, F., ve Yücel, D. (2021). Ortaöğretim öğrencilerinin uzaktan yabancllara Türkçe öğretimine bakışı (Kazakistan ve Bosna-Hersek örnekleri) . Kesit Akademi Dergisi, 7(26) , 483-499

Erzen, E., ve Ceylan, M. (2020). Covid-19 salgını ve uzaktan eğitim: uygulamalardaki sorunlar. EKEV Akademi Dergisi, 84, 224-248.

Firat, M. (2016). 21. yüzyılda uzaktan öğretimde paradigma değişimi. Yükseköğretim ve Bilim Dergisi, (2), $142-150$

Gökçe, A. T. (2008). Küreselleşme sürecinde uzaktan eğitim. Dicle Üniversitesi Ziya Gökalp Eğitim Fakültesi Dergisi, (11) , 1-12 .

Güven, A. Z. (2013). Dil bilgisi konularının öğretim sorunları. Dil ve Edebiyat Eğitimi Dergisi, 2(6), 110.

Güven, E. D., ve Cevher, N. (2005). Okul öncesi öğretmenlerinin sınıf yönetimi. Pamukkale Üniversitesi Ĕ̆itim Fakültesi Dergisi, 18(18), 71-92.

Güvenç, H. (2011), Sınıf öğretmenlerinin özerklik destekleri ve mesleki özyeterlik algıları. Kuram ve Uygulamada Ĕ̆itim Yönetimi, 17(1), 99-116.

Han F., Demirbilek, N. ve Demirtaş, H. (2021). Okul yöneticisi ve öğretmenlerin koronavirüs (Covid-19) salgını sürecinde yürütülen uzaktan eğitime ilişkin görüssleri. Cumhuriyet International Journal of Education, $1 O(3), 1168-1193$.

Herand, D., ve Hatipoğlu, Z. A. (2014). Uzaktan eğitim ve uzaktan eğitim platformları'nın karşılaştırılması. Çukurova Üniversitesi İIBF Dergisi, 18(1), 65-75.

Ilgaz, H., ve Aşkar, P. (2013). Çevrimiçi uzaktan eğitim ortamında topluluk hissi ölçeği geliştirme çalışması . Turkish Journal of Computer and Mathematics Education, 1(1), 27-34.

Kale, M (2011). Öğretmen adaylarının öğretmenlik uygulaması dersinde karşılaştıkları sorunlar. Türk Ĕ̆itim Bilimleri Dergisi, 9(2), 255 - 280.

Kalelioğlu, F., Atan, A., ve Çetin, Ç. (2016). Sanal sınıf ortamında eğitmen ve öğrenen deneyimleri. Mersin Üniversitesi Ĕ̈itim Fakültesi Dergisi, 12(2), 555-568.

Kansızoğlu, H. B., ve Erdoğan, Ş. A. M. A. (2015). Türkçe öğretmeni adaylarının sınıf yönetimine ilişkin görüşleri. Mustafa Kemal Üniversitesi Sosyal Bilimler Enstitüsü Dergisi, 12(31), 149-165.

Karakuş, M. (2020,). Online eğitim sisteminde yaşanan sorunlar. Hürriyet: https://www.hurriyet.com.tr/aile/yazarlar/merve-karakus/online-egitim-sistemindeyasanansorunlar-41628049 Erişim tarihi: 07.08.2021

Karakuş, N., ve Er, Z. (2021). Türkçe öğretmeni adaylarının web 2.0 araçlarının kullanımıyla ilgili görüşleri . IBAD Sosyal Bilimler Dergisi, (9), 177-197

Karatay, H., ve Dilekçi, A. (2019). Türkçe öğretmenlerinin dil becerilerini ölçme ve değerlendirme yeterlikleri. Millî Ĕgitim, 1(48), 685-716.

Kaya, S., ve Ağaoğlu, E. (2013). Opinions of instructors related to the physical layout dimension of virtual classroom management. Literacy Information and Computer Education Journal (LICEJ), Special Issue, 2(1), 1342-1350.

Kırksekiz, A. , Uysal, M. , İşbulan, O. , Akgün, Ö. , Kıyıcı, M., ve Horzum, M. (2015). Okul deneyimi ve öğretmenlik uygulaması derslerine eleştirel bir bakış: problemler, beklentiler ve çözüm önerileri.

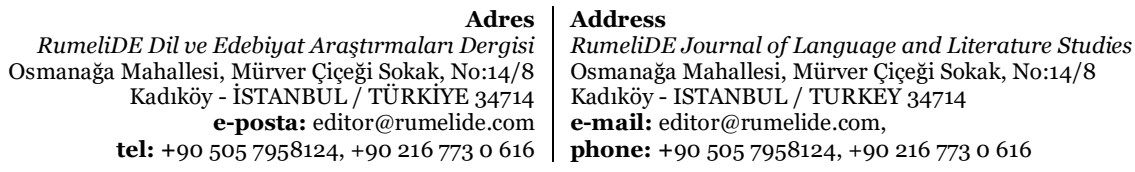


Bartin University Journal of Faculty of Education, 4(2), 433-451. DOI: 10.14686/buefad.v4i2.1082000250

Kırmacı, Ö., ve Sami, A. (2018). Kampüs öğrencilerinin eşzamanlı uzaktan eğitimde karşılaştıkları sorunlar. Eğitimde Kuram ve Uygulama, 14(3), 276-291. https://doi.org/10.17244/eku.378138

Koç, G. (2006). Yapılandırmacı sınıflarda öğretmen-öğrenen rolleri ve etkileşim sistemi. Eğilim ve Bilim, 142, 56-64.

Korkmaz, E. (2018). Yabancılara Türkçe öğretiminde yaşanan bazı sorunlar ve çözümleri. Kahramanmaraş Sütçü İmam Üniversitesi Sosyal Bilimler Dergisi, 15(1) , 89-104 .

Kurt, K. , Kandemir, M. A., ve Çelik, Y. (2021). Covid-19 Pandemi Sürecinde Uzaktan Eğitime İlişkin Sınıf Öğretmenlerinin Görüşleri . Türkiye Bilimsel Araşttrmalar Dergisi, 6(1) , 88-103.

Martin, F., ve Parker, M.A. (2014). Use of synchronous virtual classrooms: Why, Who, and How? MERLOT Journal of Online Learning and Teaching, 1O(2), 192-210.

MEB (2020a). MEB-dünya bankası güvenli okullaşma ve uzaktan eğitim projesi. https://www.meb.gov.tr/meb-dunya-bankasi-guvenli-okullasma-ve-uzaktan-egitimprojesi/haber/21536/tr Erişim tarihi: 01.12.2021

MEB (2020b). Uygulama öğrencilerinin millî eğitim bakanlı̆̆ına bağlı eğitim öğretim kurumlarında yapacakları öğretmenlik uygulamasına ilişkin yönerge. http://mevzuat.meb.gov.tr/dosyalar/1961.pdf Erişim tarihi: 10.12.2021

MEB (2021). İlkokul, ortaokul ve liselerde yüz yüze eğitim detayları belirlendi. https://www.meb.gov.tr/ilkokul-ortaokul-ve-liselerde-yuz-yuze-egitim-detaylari-

belirlendi/haber/22672/tr Erişim tarihi: 15.11.2021

Merriam, S. B. (2018). Nitel araştırma: Desen ve uygulama için bir rehber (Çev. S. Turan). Ankara: Nobel Akademi.

Öztürk, H., Kırcı, A., ve Turan, L. (2021). Covid-19 sürecinde uzaktan eğitim neye benziyor? Öğretmen adaylarının alglları . Studies in Educational Research and Development, 5(2) , 85-110 .

Öztürk, L. (2005). Türkiye'de dijital eşitsizlik-tübitak-bilten anketleri üzerine bir değerlendirme. Erciyes Üniversitesi İktisadi ve İdari Bilimler Fakültesi Dergisi, 24(1), 111-131.

Patton, M. Q. (2002). Qualitative Research and Evaluation Methods, 3d Edition. Thousand Oaks, CA: Sage Publications.

Pınarcıŏglu N. Ş., Kanbak A., ve Önver M. Ş (2021). Covid-19 pandemisi sürecinde kırsal-kentsel ve sosyo-ekonomik farklılıkların uzaktan eğitime etkisi. MSGSÜ Sosyal Bilimler Dergisi, 1(23), 2848.

Polat, E., ve Tekin, A. (2017). Öğretmen adaylarının e-içerik geliştirme becerilerinin değerlendirilmesi. Kastamonu Ĕ̆itim Dergisi, 25 (5), 1753-1770

Polat, H. ve Boydak Özan, M. (2018). Çevrimiçi öğrenme ortamlarında gerçekleştirilen sınıf yönetimi stratejilerinin öğrencilerin akademik başarı ve tutumlarına etkisi. Turkish Studies, 13(11), 1093-112.

Riasati, M. J., Allahyar, N., ve Tan, K. E. (2012). Technology in language education benefits and barriers. Journal of Education and Practice, 3(5), 25-30.

Sahin, I. ve Shelley, M. (2008). Considering students' perceptions: the distance education student satisfaction model. Educational Technology \& Society, 11(3), 216-223.

Sezgin, S. ve Firat, M. (2020). Covid-19 pandemisinde uzaktan eğitime geçiş ve dijital uçurum tehlikesi . Açıöğretim Uygulamaları ve Araştırmaları Dergisi, 6(4) , 37-54

Şen, Ö., ve Kızılcalığlu G. (2020). Covıd-19 pandemi sürecinde üniversite öğrencilerinin ve akademisyenlerin uzaktan öğretime yönelik görüşlerinin belirlenmesi. Int. J. of $3 D$ Printing Tech. Dig. Ind., 4(3), 239-252

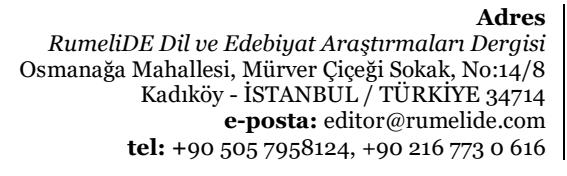

res

RumeliDE

Osmanağa Journal of Language and Literature Studies

Kadıköy - ISTANBUL / TURKEY 34714

e-mail: editor@rumelide.com,

phone: +90 $5057958124,+902167730616$ 
Tanrikulu, F. (2021). Barriers encountered by Turkish teachers in the use of digital environment and content in the distance education process . Journal of Language Education and Research, 7 (1), 78-120 . Doi: 10.31464/jlere.846432

Telli, G., Kalaç, M. Ö., ve Eronal, Y. (2020). Covid-19 mücadelesi kapsamında uzaktan eğitim sürecinde engelli öğrencilerin durumu sorunlar ve çözüm önerileri. Manisa: Manisa Celal Bayar Üniversitesi Rektörlük Basımevi.

Ünlü, S., Öztürk, H., ve Tağa T. (2014). Türkçe dersinde uygulanan sinavlar üzerine bir değerlendirme. International Journal of Social Science, 28, 513-523. Doi:10.9761/JASSS2530

Valentine, D. (2002). Distance learning: promises, problems and possibilities. Online Journal of Distance Learning Administration, 5(3).

Yeşilyurt, E., \& Çankaya, İ. H. (2008). Sınıf yönetimi açısından öğretmen niteliklerinin belirlenmesi. Elektronik Sosyal Bilimler Dergisi (elektronik), 7(23), 274-295.

Yıldırım, A. ve Şimşek, H. (2011). Sosyal bilimlerde nitel araştırma yöntemleri. Ankara: Seçkin Yayincilik.

Yıldırım, A., ve Şimşek, H. (2018). Sosyal bilimlerde nitel araştırma yöntemleri (11.baskı). Ankara: Seçkin Yayıncılık.

Yıldırım, K. (2020). İstisnai bir uzaktan eğitim-öğretim deneyiminin öğrettikleri. Alanyazın, 1 (1), 7-16

Yıldız, S. (2020). Türkçe öğretiminde teknolojik materyal kullanımı. Journal of World of Turks/Zeitschrift Für Die Welt Der Türken, 12(1), 95-115.

Yin, R. K. (2003). Case study research design and methods. Thuosand Oaks: Sage Publications

YÖK (1998). Eğitim fakültesi öğretmen yetiştirme lisans programları. Ankara: Yükseköğretim Kurulu Yayınları.

YÖK (2021). YÖK başkanı Erol Özvar, üniversitelerde yüz yüze eğitimin detaylarını açlkladı. Erişim adresi: https://www.yok.gov.tr/Sayfalar/Haberler/2021/yok-baskani-ozvar-dan-yuz-yuzeegitime-iliskin-aciklamalar.aspx

Yürektürk, F. N., ve Coşkun, H. (2020). Türkçe öğretmenlerinin teknoloji kullanımına ve teknoloji destekli Türkçe öğretiminin etkililiğine dair görüşleri. Ana Dili Ĕ̆itimi Dergisi, 8(3), 986-100o.

Zan, N. (2021). Kimya öğretmenlerinin; covid-19 sürecinde uzaktan eğitim uygulamaları hakkında görüşleri. Türkiye Kimya Dernegi Dergisi Kısım C: Kimya Egitimi, 6(2) , 241-284 . DOI: 10.37995/jotcsc.991409

Adres
RumeliDE Dil ve Edebiyat Araştırmaları Dergisi Osmanağa Mahallesi, Mürver Çiçeği Sokak, No:14/8 Kadıköy - İSTANBUL / TÜRKIYE 34714 e-posta: editor@rumelide.com tel: +90 $5057958124,+902167730616$
Address

RumeliDE Journal of Language and Literature Studies

Osmanağa Mahallesi, Mürver Çiçeği Sokak, No:14/8

Kadıköy - ISTANBUL / TURKEY 34714

e-mail: editor@rumelide.com,

phone: +90 5057958124, +90 2167730616 